\title{
Pemodelan 3D Lapisan Dasar Laut dan Identifikasi Ketebalan Sedimen Berdasarkan Kombinasi Data Pengukuran Sub-Bottom Profiler dan Single Beam Echosounder (Studi Kasus: Alur Akses Timur Surabaya)
}

\author{
(The 3d Modeling of Seabed Layer and The Identification Of Sediment Thickness Based on Combination \\ of The Measurement Data of Sub-Bottom Profiler and Single Beam Echosounder (Case Study: The \\ Surabaya East Access Channel))
}

Windy Hapsari' ${ }^{1}$ Bambang Kun Cahyono

${ }^{1}$ Alumni Departemen Teknik Geodesi FT Universitas Gadjah Mada, Indonesia

2 Dosen Departemen Teknik Geodesi FT Universitas Gadjah Mada, Indonesia

Penulis Korespondensi: Bambang Kun Cahyono | Email: bambangkun@ugm.ac.id

Diterima (Received): 30/01/2021 Direvisi (Revised): 06/12/2021 Diterima untuk Publikasi (Accepted): 10/12/2021

\begin{abstract}
ABSTRAK
Pelabuhan merupakan fasilitas umum yang memiliki peran penting dalam keselamatan navigasi pelayaran. Shipping yang aman harus didukung dengan pemantauan dan pemeliharaan secara berkala untuk mendapatkan informasi terkini tentang kedalaman, dasar laut, dan sedimentasi. Jika sedimentasi terakumulasi secara terus menerus dalam waktu singkat di alur akses (jalur pelayaran), maka dapat meningkatkan kemungkinan terjadinya kecelakaan kapal. Kajian ini mencoba memetakan dan menganalisis kondisi batimetri dan sedimentasi untuk mendukung pemantauan dan pemeliharaan rutin alur akses Timur Pelabuhan Tanjung Perak Surabaya. Metode yang digunakan adalah survei akustik berdasarkan data pengukuran Sub-Bottom Profiler (SBP) dan Single Beam Echosounder (SBES). Data yang diperoleh kemudian dikoreksi oleh Sound Velocity Profiler (SVP), data pasang surut, dan draft transduser. Kualitas data kemudian diuji berdasarkan IHO SP-44 2008 dan uji $t$-studentized dengan tingkat kepercayaan 95\%. Hasil penelitian ini adalah model 3 dimensi, profil kedalaman, ketebalan, dan volume lapisan sedimen dasar laut. Hasil penelitian menunjukkan bahwa alur akses Timur Surabaya memiliki empat lapisan dasar laut yaitu permukaan dan tiga lapisan sedimen di bawahnya. Kedalaman lapisan bervariasi antara $3 \mathrm{~m}$ sampai 16,8 m. Kualitas data kedalaman lapisan atas dikontrol oleh IHO S-44 2008 dengan nilai uji hitung 0,509 (nilai toleransi $\pm 0,509$ ), sedangkan kualitas data SBP (diukur menggunakan $t$-studentized uji) mendapatkan nilai hitung sebesar $-1,287$ dengan toleransi $\pm 1,96$. Artinya kualitas datanya bagus. Berdasarkan model $3 \mathrm{~d}$, rata-rata ketebalan lapisan secara berurutan adalah $5,84 \mathrm{~m}, 1,072 \mathrm{~m}, 0,758 \mathrm{~m}$, dan $6.355 \mathrm{~m}$, sedangkan total volume sedimen adalah 24.894.422,949 m3.
\end{abstract}

Kata Kunci: monitoring pelabuhan, alur pelayaran timur Surabaya, sub-bottom profiler, monitoring sedimentasi, model tiga dimensi

\section{ABSTRACT}

The port is a public facility with essential roles in the safety of shipping navigation. Safe shipping should be supported by regular monitoring and maintenance in order to get updated information about depth, seabed, and sedimentation. If the sedimentation is accumulated continuously in a short time in the access channel (shipping lane), it can increase the possibility of a ship accident. This study tries to map and analyze the bathymetry conditions, to support regular monitoring and maintenance of the East Access Channel of Tanjung Perak Surabaya Port. The study method is an acoustic survey based on Sub-Bottom Profiler (SBP) and Single Beam Echosounder (SBES) measurement data. Sound Velocity Profiler (SVP), tidal data, and draft transducer then correct the acquired data. The data quality is then tested based on IHO SP-44 2008 and t-studentized test with a 95\% confidence level. The results of this study are a 3-dimensional model, depth profile, thickness, and volume of the seabed sediment layer. The result shows that Surabaya's East Access Channel has four seabed layers: the top surface and three layers of sediment below. The depth of layers varies between $3 \mathrm{~m}$ to 16,8 $\mathrm{m}$. The quality of the depth data on top layers was controlled by the IHO S-44 2008 with the calculated test value of 0,5009 (the tolerance value of $\pm 0,509$ ), while the quality of the SBP data (measured using the t-studentized test) get the calculated value of $-1,287$ with a tolerance of $\pm 1,96$. It means that the quality of the data is good. Based on the $3 d$ model, the average thickness of layers sequentially is $5,84 \mathrm{~m}, 1,072 \mathrm{~m}, 0,758 \mathrm{~m}$, and 6,355 $\mathrm{m}$, while the total volume of the sediment is 24.894.422,949 $\mathrm{m} 3$.

Keywords: port monitoring, Surabaya east access channel, sub-bottom profiler, sedimentation monitoring, three-dimensional model

(C) Author(s) 2021. This is an open access article under the Creative Commons Attribution-ShareAlike 4.0 International License (CC BY-SA 4.0). 


\section{Pendahuluan}

Pelabuhan merupakan salah satu simpul dari mata rantai bagi kelancaran angkutan muatan laut dan darat. Menurut PP Kepelabuhan Nomor 61 Tahun 2009, secara umum pelabuhan diartikan sebagai wilayah yang terdiri dari daratan dan perairan, dengan batas-batas tertentu sebagai tempat kegiatan pemerintahan dan kegiatan ekonomi yang dipergunakan sebagai daerah tempat berlabuh dan aktivitas bongkar muat kapal. Salah satu pelabuhan terbesar di Indonesia adalah Pelabuhan Tanjung Perak, Surabaya. Pelabuhan Tanjung Perak termasuk ke dalam pelabuhan dengan kepadatan lalu lintas yang tinggi, baik kancah nasional maupun internasional. Hal ini menyebabkan keamanan pada alur pelayaran ini harus dapat terjamin.

Sarana alur pelayaran memegang peranan yang sangat penting bagi kelancaran arus kapal dari dan menuju pelabuhan. Hal ini dikarenakan pergerakan muatan kapal berbanding lurus dengan jumlah tonase barang, kedalaman alur laut sangat penting untuk menjamin kapasitas barang yang dibawa kapal (Josep, 2019). Analisis terhadap kedalaman laut ini dapat ditunjang dengan melakukan pemantauan dan perawatan rutin terhadap alur pelayaran pelabuhan. Pemantauan sekaligus perawatan pelabuhan ini membutuhkan informasi batimetri dan morfologi dasar laut yang dilakukan dengan survei hidrografi dengan memanfaatkan metode akustik.

Salah satu alat yang memanfaatkan metode akustik untuk dapat mengakuisisi lapisan sedimen di bawah permukaan dasar perairan yaitu Sub-Bottom Profiler. Alat SBP memiliki keterbatasan dalam akuisisi jenis-jenis lapisan tertentu seperti jenis sedimen lumpur atau jenis lapisan yang memiliki densitas rendah (de Jong, dkk., 2002). Hal ini mengakibatkan diperlukannya data pembanding dan pelengkap terhadap batimetri dasar laut guna meningkatkan akurasi kedalaman data terakuisisi. Alat yang digunakan untuk validasi permukaan dasar laut pada alur pelayaran ini adalah Single Beam Echosounder sehingga menghasilkan output yang lebih akurat.

Berdasarkan hal tersebut, melalui penelitian ini telah dilakukan kombinasi data hasil pengukuran Sub-Bottom Profiler dan Single Beam Echosounder guna analisis dasar laut dan lapisan sedimennya (Anderson \& Akingbade, 2002). Hal ini bermanfaat untuk menunjang perawatan rutin pada alur pelayaran di Pelabuhan Tanjung Perak Surabaya khususnya alur pelayaran timur yaitu dengan melakukan pemodelan tiga dimensi hasil interpretasi lapisan dasar perairan dan analisis terhadap lapisan sedimen.

\section{Data dan Metodologi}

\subsection{Data dan Lokasi}

Data yang digunakan pada kegiatan ini merupakan data hasil pengukuran menggunakan alat Sub-Bottom Profiler dan Single Beam Echosounder. Akuisisi data tersebut telah dilaksanakan tanggal 29 November 2015 oleh pihak Distrik Navigasi Kelas I Surabaya berlokasi di Pelabuhan Tanjung Perak, Surabaya dengan letak geografis pada koordinat $07^{\circ} 17^{\prime} 15,06^{\prime \prime}$ LS dan $112^{\circ} 50^{\prime} 48,84^{\prime \prime}$ BT sampai dengan $07^{\circ} 23^{\prime} 30,98^{\prime \prime}$ LS dan $112^{\circ} 58^{\prime} 03,45^{\prime \prime}$ BT.

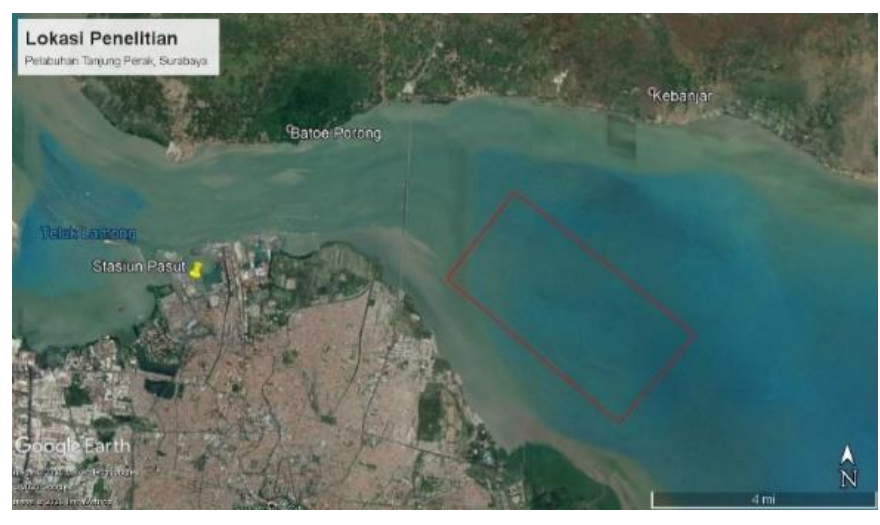

Gambar 1 Lokasi Studi Penelitian

(Sumber: Google Earth)

\subsection{Metodologi}

Kegiatan ini menggunakan dua data utama yaitu data hasil akuisisi Sub-Bottom Profiler dari Innomar dengan versi SES-2000 dan Single Beam Echosounder dari Ceeducer Pro dengan waktu akuisisi dan lokasi yang sama. Data ini diakuisisi pada tanggal 29 November 2015 di Alur Pelayaran Timur Surabaya. Data tambahan seperti data Sound Velocity Profiler dan draft transducer diakuisisi dan dicatat bersamaan dengan dilakukannya pengukuran menggunakan SBP dan SBES. Data pasang surut yang digunakan untuk koreksi, diperoleh dari Badan Informasi Geospasial dengan koordinat Pelabuhan Tanjung Perak Surabaya selama satu bulan dari tanggal 1 - 30 November 2015. Data pasang surut dan data SVP ini digunakan sebagai koreksi terhadap data Sub-Bottom Profiler dan Single Beam Echosounder untuk mendapatkan data kedalaman yang sebenarnya.

Setelah semua data yang dibutuhkan telah lengkap, pengolahan data dapat dilakukan. Data yang diakuisisi menggunakan alat SBES digunakan untuk batimetri permukaan dasar laut yang juga diukur oleh SBP. Data SBES dan SBP dikombinasikan karena tidak setiap jenis sedimen dasar laut dapat terakuisisi baik oleh SBP, sehingga memerlukan kombinasi data untuk hasil yang baik (Hapsari, 2020).

Data pasang surut diolah dengan menggunakan software Matlab untuk memperoleh kedudukan muka air. Datum yang digunakan untuk kedudukan vertikalnya yaitu LWS atau Low Water Spring. Nilai ini akan diterapkan untuk melakukan koreksi pada data Sub-Bottom Profiler dan Single Beam Echosounder sehingga memperoleh kedalaman terkoreksi terhadap data terukur. Langkah selanjutnya yaitu melakukan pemodelan 3D menggunakan metode grid dan memanfaatkan interpolasi data untuk mendapatkan 
hasil yang optimal. Selanjutnya, melakukan analisis dengan profil kedalaman, menghitung ketebalan, dan volume sedimen hasil data yang terakuisisi (Hapsari, 2020).

\section{Hasil dan Pembahasan}

Hasil pengolahan data yang dilakukan dengan koreksi pasang surut, koreksi Sound Velocity Profiler, koreksi draft transducer yaitu uji kualitas data, pemodelan 3D, serta analisis kedalaman, ketebalan dan volume pada data yang diolah.

\subsection{Hasil Pengolahan Data Sub-Bottom Profiler}

Pengolahan data hasil akuisisi Sub-Bottom Profiler menggunakan perangkat lunak Hypack 2018 dengan memanfaatkan Sub Bottom Processing. Koreksi data SBP dilakukan untuk mendapatkan hasil yang baik. Koreksikoreksi tersebut antara lain koreksi Sound Velocity, Bottom Tracking, Dynamic Range, dan Time Varying Gain (Rahili \& Cahyono, 2019).
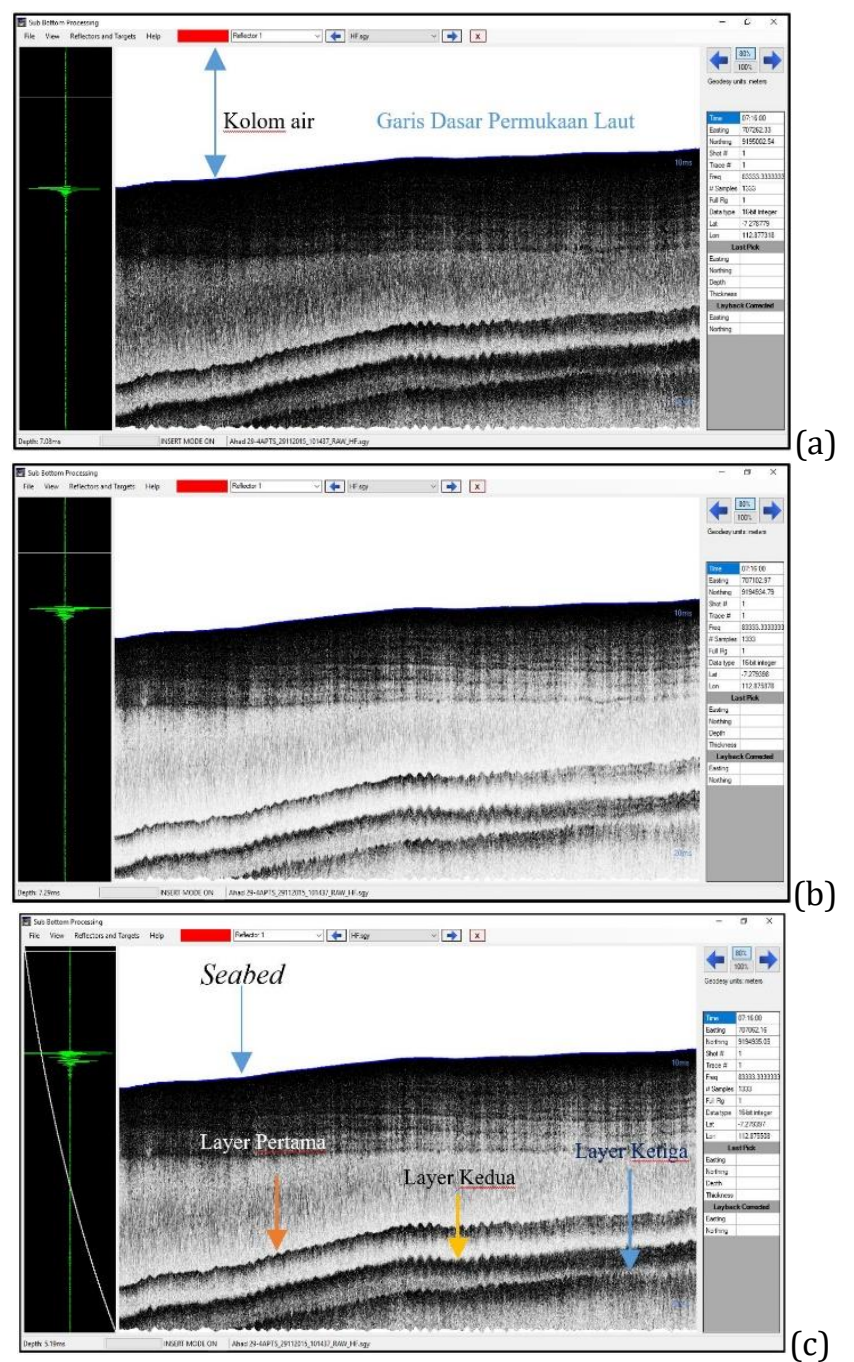

Gambar 2. Hasil Koreksi Bottom Tracking (a), Dynamic Range (b), dan Time Varying Gain (c). (Sumber: Hasil pengolahan Penulis)
Pada pengolahan Bottom Tracking dilakukan proses koreksi berupa koreksi akibat gelombang (Swell Correct), Median Filter Seabed, dan koreksi kolom air (Blank Water Column). Proses ini bertujuan untuk mendapatkan garis dasar bawah laut yang akurat sepanjang jalur survei (Hasanudin, 2005) dan ditunjukkan pada Gambar 2.(a).

Selanjutnya hasil koreksi Dynamic Range ditunjukkan pada Gambar 2.(b). Koreksi Dynamic Range bertujuan mendapatkan hasil visualisasi data yang baik dan semakin tajam. Visualisasi yang digunakan yaitu Grayscale dengan rentang intensitas cahaya minimum mulai dari 0 dan nilai maksimumnya sebesar 200. Selanjutnya koreksi Time Varying Gain. Koreksi TVG menghasilkan efek yang menyebabkan lapisan sub-bottom yang lebih keras atau lebih lembut dari sedimen di sekitarnya yang akan lebih disorot. Semakin keras bagian bawah, atenuasi semakin besar (Kruk, 2001). Hasil akhir ditunjukkan pada Gambar 2.(c).

Pada hasil akhir data yang diakuisisi SBP pada Alur Pelayaran Timur Surabaya ini didapatkan tiga lapisan sedimen di bawah seabed. Selanjutnya untuk mendapatkan nilai koordinat XYZ ketiga lapisan ini digunakan Digitasi On Screen dimana interpretasi batas lapisan dilakukan secara visual.

Berdasarkan teori reflektivitas, kontras warna yang jelas menunjukkan batas ketebalan lapisan sedimennya (Penrose, 2005). Interpretasi data dilakukan dengan membuat garis batas antara kontras warna yang berbeda. Pembuatan batas lapisan dilakukan dengan cara digitasi sesuai bentuk garis lekukan lapisan dasar laut.

Setelah mendapatkan hasil digitasi seabed dan ketiga lapisan, kemudian didapatkan konversi nilai XYZnya dalam file berformat *.txt. Pada nilai XYZ yang diperoleh dikoreksi terhadap LWS sebesar $1,2164 \mathrm{~m}$ dan draft transducer sebesar $2 \mathrm{~m}$.

\subsection{Hasil Pengolahan Single Beam Echosounder}

Data diproses menggunakan perangkat lunak Hypack 2018 dengan memanfaatkan Single Beam Editor untuk menampilkan data berformat*.raw dan melakukan koreksi SVP. Data hasil filter dikoreksi terhadap pasang surut dimana chart datum yang digunakan adalah Low Water Spring sehingga didapatkan hasil akhir Z terkoreksi.

\subsection{Uji Kualitas Data}

Berdasarkan data yang didapatkan, posisi seabed bisa diidentifikasi berdasarkan data SBP maupun data SBES. Untuk mengevaluasi kualitas dari penentuan posisi/elevasi seabed hasil pengukuran SBP, perlu dilakukan perbandingan dengan data SBES yang memang memiliki kualitas yang lebih baik. Beberapa tahapan perbandingan dilakukan dalam pengujian ini.

Terlebih dulu data seabed hasil pengukuran SBES dan SBP dibandingkan secara visual qualitative dalam pembentukan model permukaan dasar laut. Hasil pemodelan seabed data SBES dan SBP divisualisasikan pada Gambar 3. 


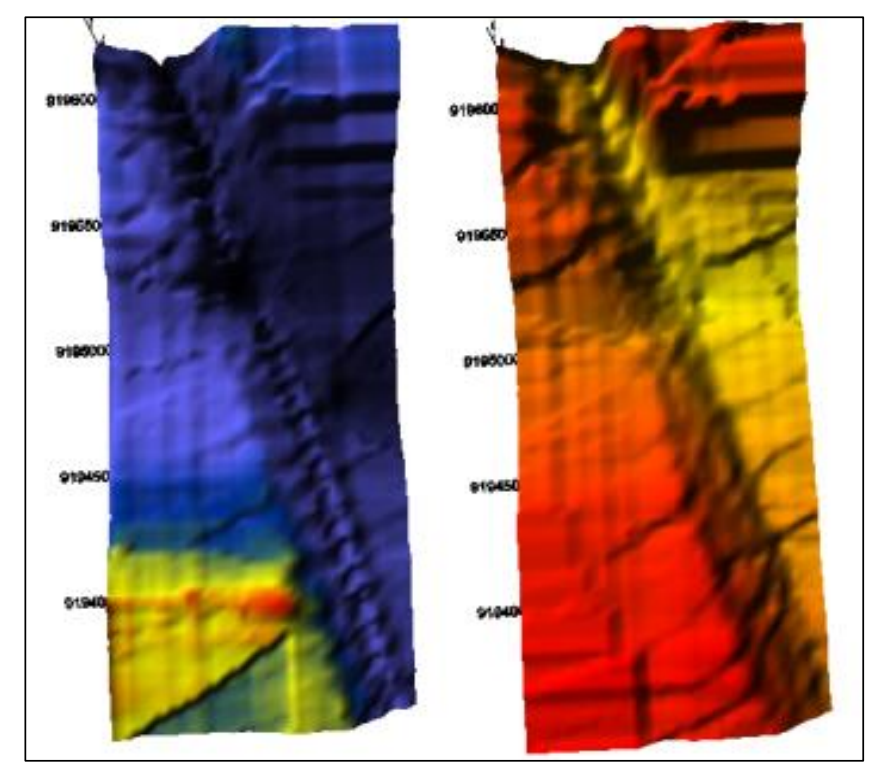

Gambar 3. Visualisasi permukaan Seabed Pengukuran SBES (biru) dan SBP (merah)

(Sumber: Hasil pengolahan Penulis)

Selanjutnya evaluasi data SBP dan SBES dilakukan dengan saling menumpang susunkan model permukaan seabed yang dihasilkan, dalam profile 3D. berdasarkan hasil ini bisa diketahui selisih tinggi kedua hasil tersebut, sehingga efek yang timbul dalam perhitungan volume diantara kedua data tersebut juga bisa diidentifikasi dengan pasti. Hasil pertampalan antara seabed data SBES dan SBP secara profil 3D, ditunjukkan Gambar 4.

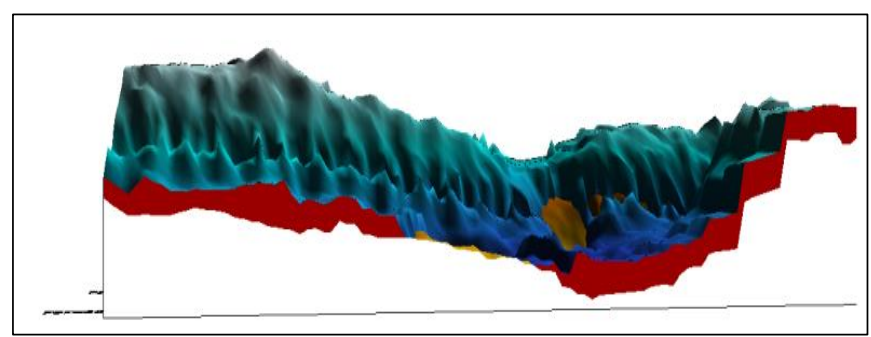

Gambar 4. Hasil Pertampalan SBES dan SBP yang

Berpotongan (Sumber: Hasil pengolahan Penulis).

Validasi untuk membuktikan adanya selisih antara hasil seabed SBES dan SBP juga dilakukan secara matematis. Perhitungan ini dilakukan dengan menghitung selisih kedalaman dan volume antara kedua lapisan. Perhitungan didapatkan selisihnya yaitu sebesar $0,53 \mathrm{~m}$ dan volume sebesar $41.240,0701 \mathrm{~m}^{3}$.

Gambar hasil pertampalan kedua data menunjukkan adanya perbedaan antara seabed yang diakuisisi oleh SBES dan SBP. Prinsip kerja Sub-Bottom Profiler sama dengan prinsip kerja Single Beam Echosounder, namun SBP menggunakan frekuensi yang jauh lebih rendah $(<10 \mathrm{kHz})$, sehingga mampu menembus lapisan dasar laut lebih dalam dibandingkan yang dapat dijangkau oleh SBES (Poerbandono \& Djunarsjah, 2005).
Untuk memastikan bahwa kualitas data SBES yang digunakan memang baik, maka perlu dilakukan pengujian kualitas data. Pengujian kualitas ini dilakukan dengan merujuk pada aturan S-44 IHO tahun 2008 (IHO, 2008). Uji kualitas data dilakukan menggunakan sampel data pertampalan antara hasil pengukuran jalur utama dan jalur silang (Dewantoro, dkk., 2012). Dalam hal ini digunakan data sejumlah 50 sampel, kemudian dilakukan dengan uji hipotesis pada tabel $\mathrm{Z}$ dengan arah dua sisi (two tailed) (Ghilani \& Wolf, 2006). Contoh pengambilan sampel data pertampalan ditunjukkan pada Gambar 5 .

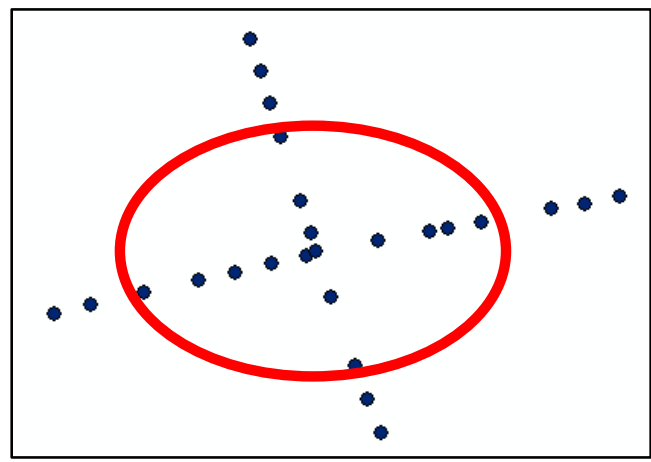

Gambar 5.. Contoh Pengambilan Titik Pertampalan (Sumber: Hasil pengolahan Penulis).

Berdasarkan pada data sampel uji yang digunakan, diketahui titik-titik yang dianggap saling bertampalan memiliki jarak antar titik paling dekat adalah $\pm 11 \mathrm{~cm}$, dan paling jauh pada jarak $\pm 32 \mathrm{~cm}$

Hasil Uji terhadap tabel $\mathrm{Z}$ menggunakan tingkat kepercayaan sebesar 95\%. Hasil perhitungan toleransi $\mathrm{Z}_{0}$ nya berada pada nilai $\pm 1,96$ dan hasil dari nilai $\mathrm{Z}$ hitungnya adalah sebesar -1,287. Hasil nilai $\mathrm{Z}$ hitung ini dapat dikategorikan masuk dalam nilai toleransi tabel $\mathrm{Z}$ yang memiliki rentang $\pm 1,96$, sehingga disimpulkan bahwa data hasil akuisisi memiliki kualitas yang baik.

Kemudian data diuji dengan perhitungan toleransi pada IHO S-44 tahun 2008 yang hasilnya dijabarkan pada Tabel 1.

Tabel 1 Hasil Uji Kualitas Data

\begin{tabular}{ccc}
\hline No & Parameter & Nilai \\
\hline 1 & a & 0,5 \\
2 & b & 0,013 \\
3 & Depth Mean & $-7,42475 \mathrm{~m}$ \\
4 & Mean Eror $(\hat{H})$ & 0,052 \\
5 & Total $(H i-\hat{H})$ & $2,54684 \mathrm{~m}$ \\
6 & Standar & 0,255546 \\
& Deviasi (Sh) \\
7 & Sh x 1,96 & 0,500869 \\
8 & Toleransi IHO & 0,509103 \\
& Orde 1b \\
\hline
\end{tabular}

(Sumber: Hasil pengolahan Penulis).

Hasil uji data yang dijabarkan dalam tabel di atas menunjukkan bahwa data hasil akuisisi pada lajur utama dan lajur silang memiliki rata-rata kedalaman sebesar 7,42475 m dengan rerata selisih kedalaman sebesar 0,052 
m. Berdasarkan IHO SP-44 dengan menggunakan tingkat kepercayaan 95\% didapatkan selisih hasil nilai kedalaman sebesar 0,500869. Hasil ini kemudian dibandingkan dengan nilai toleransi yang mengacu pada IHO SP-44 Tahun 2008 untuk orde 1b yang memiliki nilai 0,509103. Berdasarkan hasil perbandingan uji kualitas data tingkat kepercayaan 95\% dengan hasil nilai toleransi berdasarkan SNI, dapat disimpulkan bahwa hasil data akuisisi masuk nilai dalam batas toleransi IHO SP-44 Orde $1 \mathrm{~b}$.

\subsection{Model 3 Dimensi}

Data hasil akuisisi SBP menunjukkan bahwa pada Alur Pelayaran Timur Surabaya memiliki empat lapisan pada dasar laut. Pada pemodelan tiga dimensi dan perhitungan volume serta ketebalan yang dilakukan pada seabed adalah hasil akuisisi dari alat SBES. Data hasil akuisisi yang dimodelkan sepanjang $5 \mathrm{~km}$ dengan 40 jalur utama dan 1 jalur silang dimana tiga lapisan di bawah permukaan dasar laut hasil akuisisi SBP diinterpretasi secara visual menggunakan digitize on screen.

\subsubsection{Pemodelan lapisan permukaan dasar laut (Lapisan} Pertama)

Pada hasil pemodelan lapisan pertama dilakukan interpolasi garis kontur dengan kedalaman seabed antara 3,2 m sampai 8,4 m. Kontur mayornya memiliki nilai 6,6 m dan 7,1 m dengan interval kontur yaitu 0,5 m. Hasil penggambaran garis kontur data pada seabed ditunjukkan pada Gambar 6..(a). Data juga dimodelkan secara 3D dengan hasil yang divisualisasikan pada Gambar 6..(b).
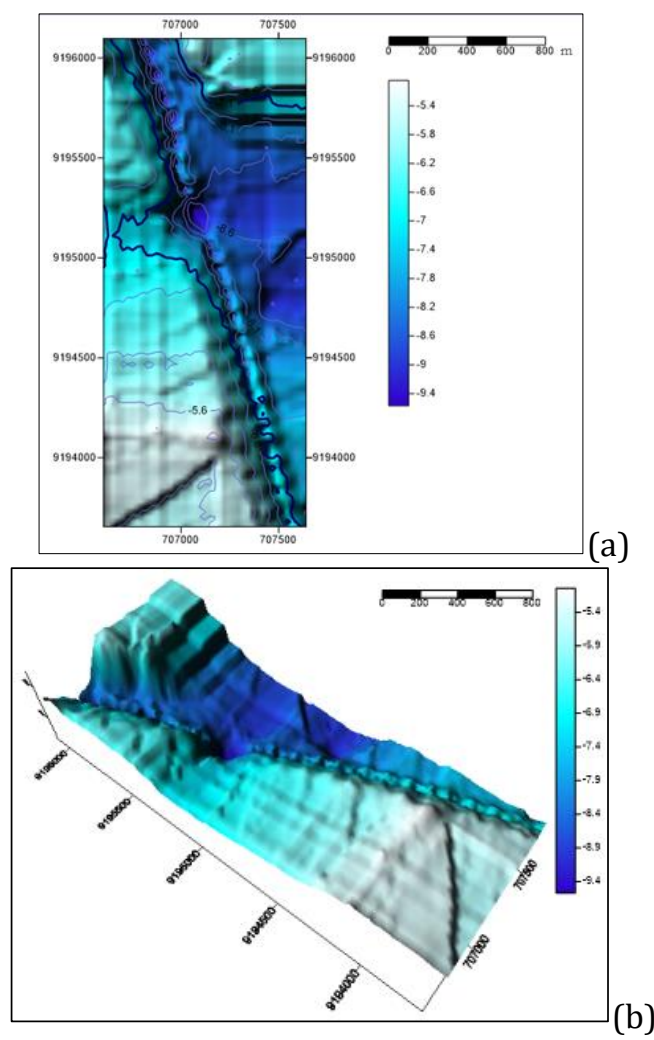

Gambar 6.. Pemodelan permukaan seaded dalam 2D (a) dan 3D (b). (Sumber: Hasil pengolahan Penulis)
Hasil dari pemodelan 3 dimensi menunjukkan keadaan permukaan dasar laut secara real. Warna yang digunakan memvisualisasikan keadaan permukaan dimana semakin tua warna biru berarti permukaan laut semakin cekung atau semakin dalam.

\subsubsection{Pemodelan Lapisan Kedua}

Lapisan 2 memiliki kontur mayor dengan nilai $10 \mathrm{~m}$ dan $12,5 \mathrm{~m}$ dan interval kontur 0,5 m. Hasil pemodelan permukaan dan interpolasi garis kontur ditunjukkan pada Gambar 7..(a). Lapisan kedua ini juga disajikan dalam model permukaan 3D sebagaimana yang ditunjukkan pada Gambar 7..(b).

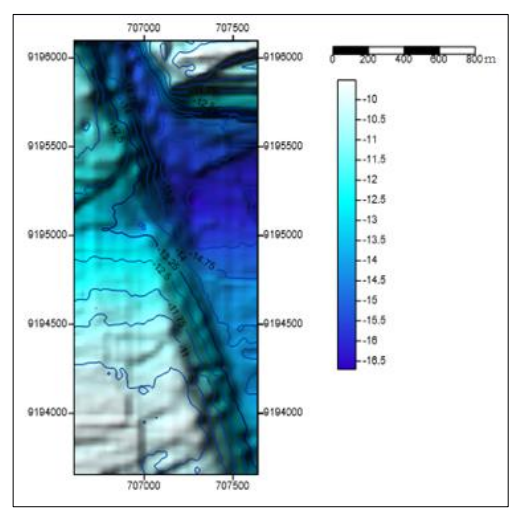

(a)

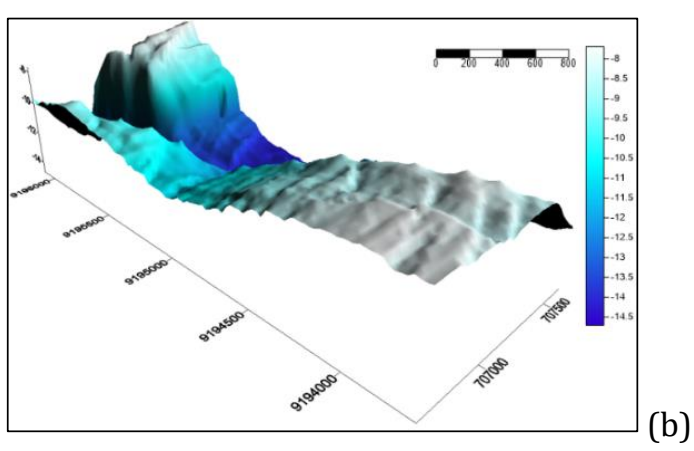

Gambar 7. Hasil Pemodelan Lapisan Dua dalam 2D (a) dan 3D (b). (Sumber: Hasil pengolahan Penulis)

Pemodelan 3 dimensi lapisan kedua ini memiliki permukaan yang tidak jauh berbeda dari seabed. Hal ini mengindikasikan bahwa bentuk atau pola lapisan sama dengan bentuk lapisan di atasnya.

\subsubsection{Pemodelan Lapisan Ketiga}

Lapisan 3 memiliki rentang kedalaman antara $10 \mathrm{~m}$ sampai dengan 16,5 m di mana memiliki nilai kontur mayor $12 \mathrm{~m}$ dan 14,5 m. Agar memiliki gambaran yang lebih baik untuk lapisan ketiga ini, maka dicoba untuk disajikan dalam pemodelan 2D dan 3D sebagaimana yang disajikan pada Gambar 8.. berikut.

Dalam pemodelan tiga dimensi lapisan ketiga ini, nampak memiliki pola morfologi yang hampir sama dengan lapisan kedua dan lapisan seabed. 


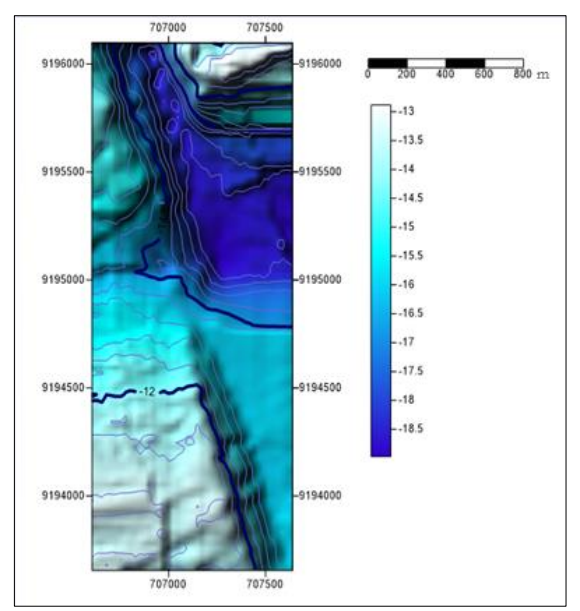

(a)

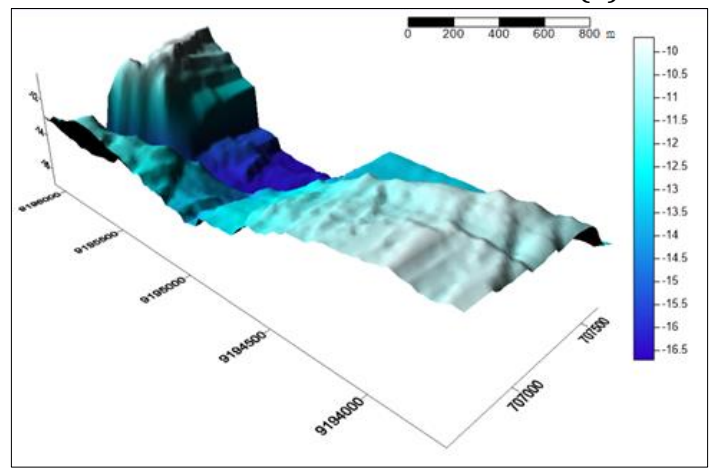

(b)

Gambar 8.. Hasil pemodelan permukaan lapisan ketiga dalam 2D (a) dan 3D (b).

(Sumber: Hasil pengolahan Penulis)

\subsubsection{Pemodelan Lapisan Keempat}

Lapisan keempat memiliki rentang kedalaman antara 12 m sampai dengan $16,8 \mathrm{~m}$. Pada lapisan ini memiliki nilai kontur mayor $13 \mathrm{~m}$ dan $15 \mathrm{~m}$. Sebagaimana lapisan-lapisan sebelumnya, pada lapisan keempat ini juga dicoba disajikan dalam tampilan 2D yang dilengkapi dengan garis kontur, dan visualisasi 3D, sebagaimana yang disajikan pada Gambar 9..(a) dan (b).

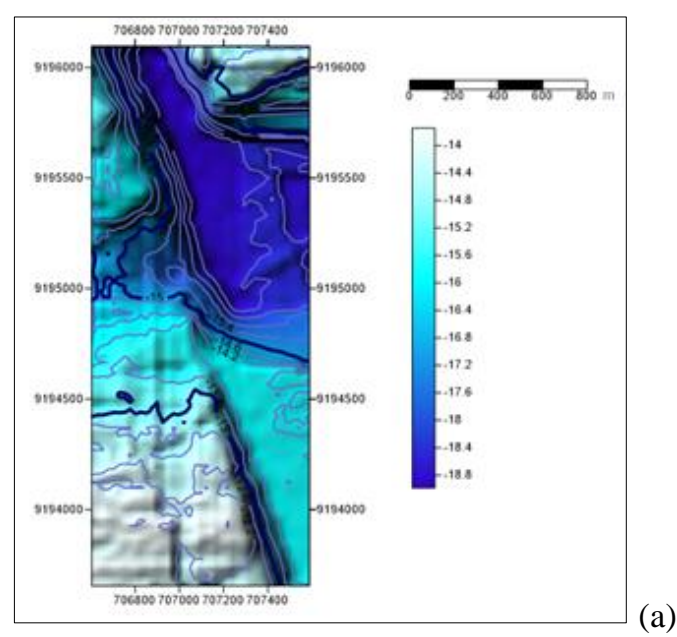

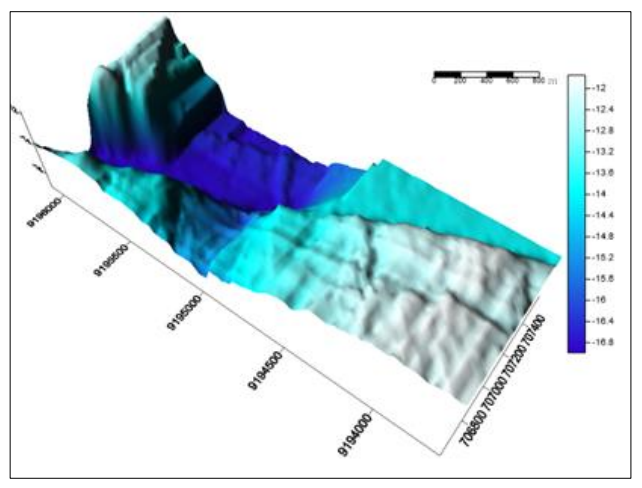

(b)

Gambar 9.. Hasil visualisasi lapisan keempat dalam 2D (a) dan 3D (b).

(Sumber: Hasil pengolahan Penulis)

Pemodelan tiga dimensi lapisan keempat dengan kedalaman diantara 12 Pemodelan tiga dimensi lapisan keempat dengan kedalaman diantara $12 \mathrm{~m}$ hingga 16,5 m dimana warna yang semakin tua berarti semakin dalam.

\subsubsection{Overlay Keempat Lapisan}

Untuk memberikan kenampakan visual yang lebih baik antar lapisan yang telah disajikan pada sub-bab sebelumnya, maka penyajian kombinasi keempat lapisan dirasa penting untuk dilakukan. Hasil dari masing-masing pemodelan layer setiap lapisan ditumpangsusunkan untuk mengetahui gambaran posisi relatif antara satu lapisan dengan lapisan lainnya. Hasil visualisasi keempat lapisan, disajikan dalam Gambar 10.

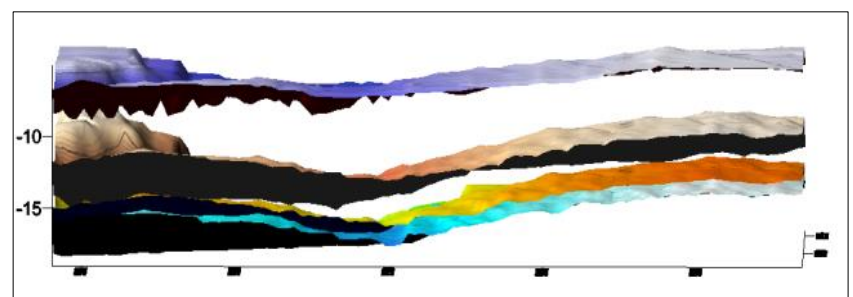

(a)

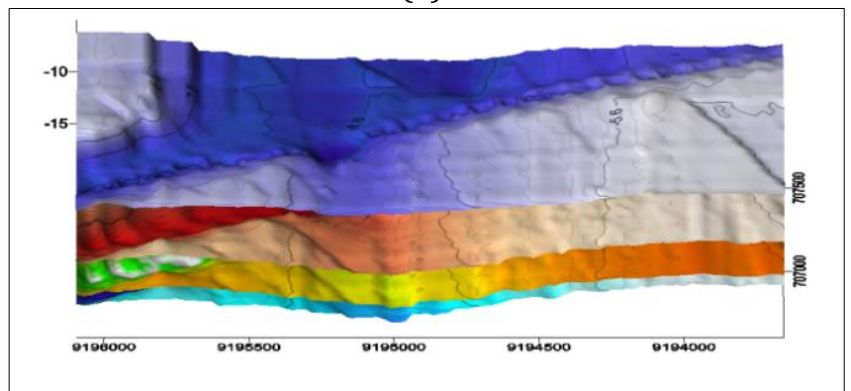

(b)

Gambar 10.. Hasil visualisasi keempat lapisan dari sudut pandang samping (a) dan isometrik (b).

(Sumber: Hasil pengolahan Penulis)

Pemodelan antar lapisan dibutuhkan untuk mendapatkan gambaran hasil akhir lapisan pada Alur Pelayaran Timur Surabaya. Pemodelan seluruh data dan 
penggabungan seluruh lapisan dilakukan untuk dapat melihat visualisasi tiga dimensi kondisi lapisan tanah di bawah alur Pelayaran Timur Surabaya secara menyeluruh.

Untuk mendapatkan gambaran yang lebih baik, dilakukan penggambaran profil melintang sehingga kenampakan lapisan seabed bisa didapatkan. Posisi garis profil diambil di atas model seabed hasil, sebagaimana yang disajikan pada Gambar 11. Adapun profil seabed yang dihasilkan ditunjukkan pada Gambar 12.(a), hingga (c) untuk setiap warna garis.

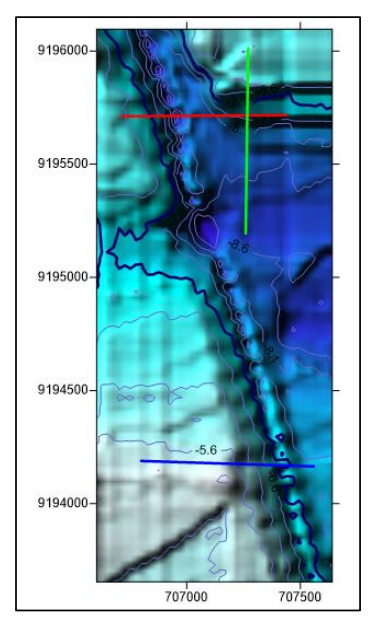

Gambar 11.. Posisi Garis Sampel Profil Melintang

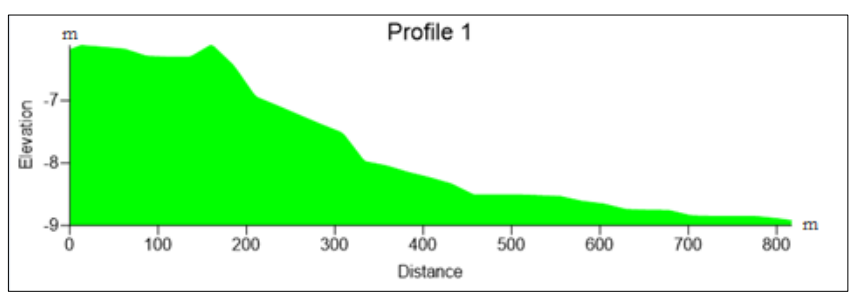

(a)

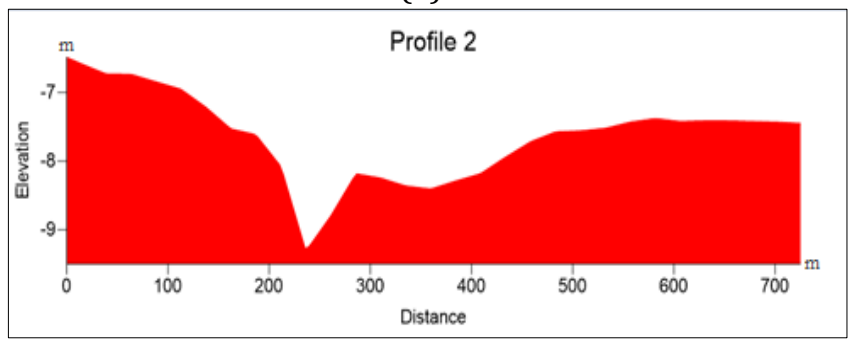

(b)

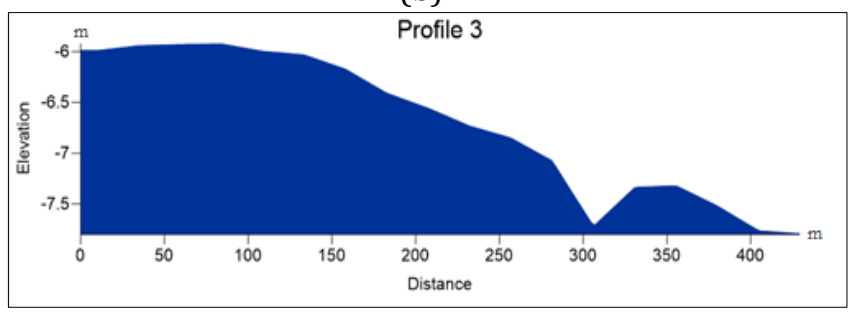

(c)

Gambar 12. Gambaran Profil Melintang pada garis hijau (a), merah (b), dan biru (c).

(Sumber: Hasil pengolahan Penulis)

3.5. Analisis Perhitungan Volume dan Ketebalan Lapisan
Perhitungan volume dan ketebalan dilakukan antara data seabed dengan lapisan sedimen pertama, lapisan pertama dan lapisan kedua, lapisan kedua dengan lapisan ketiga serta lapisan ketiga hingga batas maksimal kedalaman.

Metode cut and fill dipilih untuk mengetahui volume ketebalan sedimen. Nilai yang digunakan untuk analisis perhitungan volumenya adalah nilai cut karena lapisan tidak berpotongan (Rahili \& Cahyono, 2019). Nilai volume dan ketebalan yang dihasilkan setelah perhitungan antar lapisan disajikan pada Tabel 2.

Tabel 2 Hasil Perhitungan Ketebalan dan Volume setiap Lapisan

\begin{tabular}{|c|c|c|c|}
\hline No & Batas Lapisan & $\begin{array}{l}\text { Ketebalan } \\
\text { Rerata(m) }\end{array}$ & Volume $\left(\mathrm{m}^{3}\right)$ \\
\hline 1 & $\begin{array}{l}\text { Dasar permukaan } \\
\text { hingga lapisan } \\
\text { pertama }\end{array}$ & 5,839976 & $14.097 .100,519$ \\
\hline 2 & $\begin{array}{l}\text { Lapisan pertama } \\
\text { hingga lapisan } \\
\text { kedua } \\
\text { Lapisan kedua }\end{array}$ & 1,07257 & $2.342 .952,728$ \\
\hline 3 & $\begin{array}{l}\text { hingga lapisan } \\
\text { ketiga }\end{array}$ & 0,757643 & $1.810 .604,624$ \\
\hline 4 & $\begin{array}{l}\text { Lapisan ketiga } \\
\text { hingga batas } \\
\text { maksimal } \\
\text { kedalaman }\end{array}$ & 6,355187 & $6.643 .765,078$ \\
\hline
\end{tabular}

Nilai ketebalan sedimen diperoleh dari hasil analisis data yang didapatkan berdasarkan digitasi reflektor terhadap masing-masing lapisan. Hasil digitasi ini menghasilkan nilai kedalaman juga mendapatkan nilai ketebalan yang dianalisis.

Pada ketebalan lapisan permukaan dasar laut atau seabed memperoleh hasil sebesar 5,84 m dimana ketebalan ini diukur dari seabed hingga batas lapisan pertama. Hasil digitasi lapisan pertama memperoleh rata-rata ketebalan sebesar 1,07 m hingga batas lapisan kedua. Lapisan kedua memiliki ketebalan sebesar $0,76 \mathrm{~m}$ yang merupakan lapisan paling tipis dibandingkan ketebalan lapisan yang lain. Lapisan terakhir yaitu lapisan ketiga yang memiliki nilai 6,36 m dimana batas lapisan ketiga dihitung hingga batas maksimal atau kedalaman terbesar yang terakuisisi oleh alat Sub Bottom Profiler. SBP merupakan alat yang sesuai apabila survei yang dilaksanakan bertujuan untuk analisis sedimen dasar perairan, namun akan lebih baik apabila adanya validasi ketebalan supaya dapat dijadikan bahan pertimbangan keakuratan data.

\section{Kesimpulan}

Berdasarkan hasil dan pembahasan penelitian, dapat disimpulkan bahwa Penyajian model 3 dimensi dasar laut Alur Pelayaran Timur Surabaya telah didapatkan dengan kombinasi hasil akuisisi data Single Beam Echosounder dan Sub-Bottom Profiler. Terdapat perbedaan hasil akuisisi data 
antar kedua alat terhadap dasar permukaan laut sebesar $0,53 \mathrm{~m}$. Hal ini dapat disebabkan oleh perbedaan interpolasi antar titik pada data dan perbedaan frekuensi pada alat yang digunakan sehingga berpengaruh terhadap ketelitian dan keakuratan pada alat saat akuisisi data.

Hasil analisis profil kedalaman dari lapisan dasar laut berdasarkan SBP dan SBES menunjukkan bahwa kedalaman dari permukaan hingga lapisan sedimen terdalam menunjukkan rentang $3 \mathrm{~m}$ hingga 16,8 m dengan karakteristik bentuk permukaan dan lapisan di bawahnya yang hampir sama. Terdapat tiga lapisan di bawah permukaan dasar laut dimana pada penghitungan nilai ketebalan dan volumenya menggunakan dasar permukaan hasil akuisisi SBES dimana hasil nilai masing masing ketebalan antara lain 5,83 m, 1,07 m, 0,76 m, dan 6,36 m dengan total volume sebesar $24.894 .422,949 \mathrm{~m}^{3}$.

\section{Pernyataan Konflik Kepentingan}

Penulis menyatakan tidak ada konflik kepentingan dalam artikel ini.

\section{Referensi}

Anderson, N., \& Akingbade, A. (2002). Overview of The Shallow Seismic Reflection Technique. The $2^{\text {nd }}$ Annual Conference on the Application of Geophysical and NDT Methodologies to Transportation Facilities and Infrastucture. California.

de Jong, C. D., Lachapelle, G., Skone, S., \& Elema, I. A. (2002). Hydrography. Delft University Press. Delf. The Netherlands.

Dewantoro, A., Sabri, L., \& Sasmito, B. (2012). Analisis Ketelitian Hasil Pemeruman Perairan Dangkal Menggunakan Multibeam Echosounder. Jurnal Geodesi Undip, 1(1), 96311.

Ghilani, C. D., \& Wolf, P. R. (2006). Adjustment Computations Spatial Data Analyses 4th Edition (Fourth Edi). John Wiley \& Sons, Inc. https://doi.org/10.1038/ni1566.
Hapsari, W. (2020). Pemodelan 3D Lapisan Dasar Laut dan Identifikasi Ketebalan Sedimen Berdasarkan Kombinasi Data Pengukuran Sub-Bottom Profiler dan Single Beam Echosounder (Studi Kasus: Alur Pelayaran Timur Surabaya). Universitas Gadjah Mada.

Hasanudin, M. (2005). Teknologi seismik refleksi untuk eksplorasi minyak dan gas bumi. Teknologi Seismik Refleksi Untuk Eksplorasi Minyak Dan Gas Bumi, XXX(4), 1-10.

IHO. (2008). International Hydrographic Organization Standards for Hydrographic Surveys 5th Edition Special Publication No. 44 (International Hydrographic Organization (ed.); 5th ed.). International Hydrographic Bureau.

Josep, A. A. (2019). Analisis Manfaat dalam Proyek Pengerukan (Studi Kasus: Alur Pelayaran Surabaya Timur). Jurnal Penelitian Transportasi Laut, 21, 35-40 Kruk, V. Der. (2001). Reflection Seismic 1. Institut für Geophysik ETH, Zürich.

Nurdiyanto, B., Hartanto, E., Ngadmanto, D., Sunardi, B., \& Susilanto, P. (2011). Penentuan Tingkat Kekerasan Batuan Menggunakan Metode Seismik Refraksi. Jurnal Meteorologi Dan Geofisika, 12(3), 211-220. https://doi.org/10.31172/jmg.v12i3.103

Penrose, J. D., Siwabessy, P. J. W., Gavrilov, A., Parnum, I., Hamilton, L. J., Bickers, A., Brooke, B., Ryan, D. A., \& Kennedy, P. (2005). Acoustic Techniques for Seabed Classification. Cooperative Research Centre for Coastal Zone Estuary and Waterway Management, September, 141.

Poerbandono, D. N., \& Djunarsjah, E. (2005). Survei Hidrografi. Cetakan Ke-1. PT Refika Aditama. Bandung.

Rahili, N. R., \& Cahyono, B. K. (2019). 3D Modeling and Volume Estimation of Riverbed Layers Based on Sub Bottom Profiler Measurement Data. JGISE: Journal of Geospatial Information Science and Engineering, 2(1), 113-120. https://doi.org/10.22146/jgise.39974 